\begin{tabular}{lllll}
\hline ISSN 0258-2279 & Literator & 9 & No. 1 & April 1988 \\
\hline
\end{tabular}

\title{
Kobus Petzer \\ Die tekskritiese notas by die Nuwe Testament van die nuwe Afrikaanse vertaling
}

\begin{abstract}
The article contains a discussion of the problems of the inclusion of text-critical commentary in a translation of the Bible. The New Testament of the new Afrikaans translation of 1983 is taken as example. Four such problems are discussed: (a) the choice of the texts which are to be supplied by such commentary; (b) the formulation of the notes; (c) the use of brackets in the text; and (d) the inclusion of an introduction.
\end{abstract}

Onder die talle interessanthede en nuwe eienskappe van die nuwe Afrikaanse vertaling van die Bybel van 1983 (NAB) is die enkele tekskritiese notas in die onderste kantlyn in veral die Nuwe Testament (kyk Mt. 6:13; 17:20; 18:11; 23:14; Mk. 7:15; 9:43, 44; 11:25; 15:27; 16:9; Lk. 17:36; 23:17; Jh. 5:3; 7:53; Hd. 8:36; 15:33; 24:6; 28:28; Rm. 16:23). Hoewel die gebruik om in 'n vertaling na die grondteks of die manuskripte van die Griekse Nuwe Testament te verwys, vir die Afrikaanse leser vreemd is, is dit 'n gebruik wat 'n tyd lank reeds in ander vertalings gevolg is. Die New English Bible, die Oxford Annotated Bible, die New American Bible, en later uitgawes van die Revised Standard Version en die Moffat-vertaling is voorbeelde van Engelse vertalings met sulke notas. Met die gebruik as sodanig is weinig fout te vind. Tog is daar talle probleme in die saamstel en aanbring van sulke notas, wat die waarde daarvan kan relativeer. Van hierdie probleme is duidelik in die notas in die NAB en sy voorgangers, die Nuwe Testament en Psalms van 1979 (NTP) en die Blye Boodskap van 1975 (BB) sigbaar. In hierdie artikel word 
enkele van die probleme aan die hand van die notas in die NAB bespreek. Veral vier sodanige probleme kan geïdentifiseer word:

(a) Watter tekste moet sulke notas kry?

(b) Hoeveel inligting moet in die notas weergegee word?

(c) Moet blokhakies in die teks gebruik word?

(d) Moet 'n inleiding waarin die basiese aspekte van die probleem bespreek word, by die vertaling ingesluit word?

Omdat die eerste twee probleme verreweg die belangrikste is, word die meeste aandag in die artikel daaraan gegee.

\section{Die keuse van tekste}

Die eerste probleem is die keuse van die tekste wat van notas voorsien moet word.

Hierdie probleem staar nie alleen die Bybelvertaler in die gesig nie, maar is ook 'n groot probleem vir samestellers van die oorspronklike Griekse teks, waarop die vertaling gebaseer word. In die ongeveer 5000 manuskripte van die Griekse Nuwe Testament wat vandag beskikbaar is, kom daar ongeveer 250000 ('n kwart miljoen!) variante lesings voor. Die gevolg is dat geen enkele teks bestaan wat al die verskille in sy tekskritiese apparaat weergee nie. Daarom moet alle tekssamestellers selekteer en slegs die belangrikste variasie in die kritiese apparaat weergee. Die samestellers van die teks wat as grondteks van die NAB gebruik is, dit is die 3e uitgawe van The Greek New Testament deur die Verenigde Bybelgenootskappe (UBS3), beperk hulle tekskritiese apparaat tot dié variasie-eenhede wat volgens hulle 'n invloed op vertaling het (Markham, 1966:108; Finegan, 1974:69). Alleen hierdie variasie-eenhede is ongeveer 1400 in totaal, en volgens sommige kritici van hierdie teks is sommige belangrike variasie-eenhede nie in die apparaat opgeneem nie (Elliott, 1973:279-283; 1975:325; Kilpatrick, 1978:3-5). Die 26e uitgawe van die bekende Nestle-Aland reeks (NA26), wat dieselfde teks as UBS3 bevat, bevat weer alle variasie-eenhede wat deur die loop van die eeu deur tekssamestellers as belangrik beskou is (kyk Junack, 1978:136). Dit beloop ongeveer 'n totaal van 10000 variasie-eenhede.

Binne hierdie konteks moet ook die Bybelvertaler sy keuse onder die magdom inligting maak en moet hy 'n kriterium vir homself stel om te bepaal watter tekste hy van sulke notas gaan voorsien en watter nie. Die vertalers van die $\mathrm{NAB}$ bespreek nie hul keuse van die tekste wat notas kry nie. Gevolglik moet die kriteria wat hulle gebruik het, uit die notas self afgelei word. Word die notas ontleed, blyk dit dat die vertalers waarskynlik slegs dié gedeeltes van so 'n nota voorsien het, waar 'n groterige verskil met die ou Afrikaanse vertaling van 1933/53 (OAB) voorkom en waar dit lyk of die vertalers van die NAB 'n bekende deel uitgelaat het. Verreweg die meeste gevalle wat hierbo genoem is, voldoen aan hierdie vereiste. 
Daar is egter twee uitsonderings wat hierdie afleiding problematies maak. Die eerste is die notas by die slot van Markus (Mk. 16:9) en die perikoop van die owerspelige vrou (Jh. 7:53). In albei gevalle word die notas by 'n teks gevoeg waar geen verskille tussen die NAB en OAB voorkom nie. In die NTP en BB is die saak nog meer problematies, aangesien hierdie twee gedeeltes in blokhakies geplaas is. In die BB word dieselfde praktyk ook nog by Lukas $22: 19 b-20 ; 43-44$ en 23:34 gevolg. Al drie hierdie tekste word tussen blokhakies geplaas en van 'n nota voorsien.

Die vraag wat hier na vore kom, is waarom die NAB in hierdie twee gevalle van hul oënskynlike kriterium afwyk deur die betrokke twee gedeeltes van notas te voorsien, as daar geen verskil tussen die NAB en OAB op hierdie plekke is nie. Die notas in die NTP en BB is verstaanbaar, aangesien die outentisiteitsprobleem van die betrokke gedeeltes in daardie tekste deur middel van die blokhakies aangedui word. Die verwydering van die blokhakies wat in die BB by die drie genoemde tekste in Lukas voorgekom het, het ook tot die verwydering van die notas by die betrokke tekste in die NTP gelei. In die NAB is die blokhakies wat in die NTP by Markus 16:9-20 en Johannes 7:53-8:11 voorgekom het, ook verwyder. Waarom is die notas nie ook na analogie van die gebruik in die NTP ten opsigte van die drie tekste in Lukas weggelaat nie? Of, aan die ander kant, waarom is die ander drie tekste in Lukas na analogie van die voetnote by Markus 16:9 en Johannes 7:53 nie ook van voetnote voorsien nie?

Aansluitend hierby is die status quo in die NAB enigsins misleidend en verwarrend. Dit wek naamlik die indruk dat die vertalers in die betrokke gedeeltes van die grondteks afgewyk het en die twee gedeeltes op grond van later en swakker getuienis by die teks ingesluit het. Op hierdie wyse ondergrawe hulle die gesag van die grondteks, waarop hulle hul in die ander gevalle beroep. Dit sou waarskynlik beter gewees het om slegs maar die notas by die betrokke twee gedeeltes weg te laat.

Die tweede saak wat die afleiding ten opsigte van die kriteria vir die keuse van die tekste wat van notas voorsien moet word, problematies maak, is die weglating van notas by ander dele wat ook nie in die NAB voorkom nie, soos die bekende comma Iohanneum (1 Jh. 5:7-8).

Die probleem ten opsigte van die tekste wat van sulke notas voorsien moet word, hang nou saam met die doel van die notas:

- Indien die notas bedoel is om moontlike weerstand teen die vertaling te antisipeer, om dus die gebruiker van die teks in te lig waarom langer dele, wat uit ' $n$ vorige vertaling aan hom bekend is, in die nuwe vertaling ontbreek of verander is, is dit slegs nodig om die betrokke gedeeltes van notas te voorsien. In so 'n geval sou egter 'n meer konsekwente aanbring van notas in die NAB verwag kon word. Addisionele notas by tekste soos 1 Johannes 5:7-8 (die weglating van "die drie hemelse getuies") of 1 
Korintiërs 13:3 (die vervanging van "om verbrand te word" met "om my daarop te kan beroem") sou in die lig hiervan verwag kon word. In so 'n geval is dit ook onnodig om Markus 16:9 en Johannes 7:53, waar daar geen verskil tussen die $\mathrm{OAB}$ en $\mathrm{NAB}$ is nie, van 'n nota te voorsien. Die vraag is egter of dit enigsins nodig is om notas by elke plek te plaas, indien bogenoemde die doel van sulke notas is. Die hele saak kan goedskiks met 'n enkele sin in ' $n$ inleiding of voorwoord verduidelik word.

- Aan die ander kant kan die doel van sulke notas wees om inligting ten opsigte van tekskritiese kwessies te verskaf ten einde die gebruiker oor die problematiek van die samestelling van die grondteks in die algemeen in te lig. In so'n geval kan egter verwag word dat daar heelwat meer notas in die vertaling gevoeg sal word. 'n Riglyn kon wees om ten minste die gevalle waar die verandering in die grondteks 'n direkte invloed op die vertaling gehad het, met ander woorde, ten minste die tekste wat in die UBS3 van 'n tekskritiese apparaat voorsien is, ook in die vertaling van notas te voorsien. Sou dit die doel van die notas wees, is dit korrek om Markus 16:9 en Johannes 7:53 van notas te voorsien, maar dan moet meer konsekwent opgetree word en ander gevalle ook van notas voorsien word.

\section{Die formulering van die notas}

Die tweede probleem ten opsigte van die insluiting van tekskritiese notas by 'n vertaling hang nou saam met die eerste en sentreer om die formulering van die notas, anders gestel, die vraag hoeveel inligting en watter soort inligting gegee moet word.

Die probleem wat hier na vore tree, is soos in die geval van die vorige, nie eie aan die saamstel van tekskritiese notas vir 'n vertaling nie. Die samestellers van Griekse tekste het dieselfde probleem. Omdat daar so 'n geweldige aantal manuskripte, ou vertalings en kerkvadertekste bestaan wat die Nuwe Testament in geheel of ten dele bevat, is dit onmoontlik om alle inligting in die tekskritiese apparaat van 'n Griekse teks weer te gee (kyk Elliott, 1986: 125-143 vir die bespreking van die probleme waarmee die samesteller van so 'n apparaat te doen het). Selfs in die apparaat van die teks van Lukas deur die International Greek New Testament Project (Oxford GNT), die mees volledige apparaat tot dusver, word nie alle variante lesings van al die beskikbare teksgetuienisse gebied nie en moes daar geselekteer word. Hierdie seleksieproses vind soveel te meer plaas wanneer die kritiese apparaat van hand- of sakuitgawes van die Griekse Nuwe Testament voorberei word. Die mees beduidende verskille tussen UBS3 en NA26 raak hierdie aspek. Omdat UBS3 bedoel is as ' $n$ teks wat vir vertaling gebruik moet word, en NA26 bedoel is as 'n teks vir iemand met 'n groter belangstelling in tekskritiese sake (kyk Junack, 1978:136), bevat UBS3 minder variasie-eenhede in die apparaat, maar meer inligting by elke variasie-eenheid, terwyl NA26 meer variasieeenhede bevat, maar minder inligting by elke variasie-eenheid. Nie een van die twee tekste is egter naastenby volledig, of bedoel om volledig te wees nie. 
Vir die vertaler wat tekskritiese notas by sy vertaling wil insluit, openbaar hierdie probleem homself in besonder in twee opsigte, wat andermaal duidelik in die NAB en sy voorgangers se tekste weerspieël word:

Die eerste probleem wat opgelos moet word, is hoeveel variante lesings in die betrokke variasie-eenheid in die nota bepreek moet word. Anders gestel: moet alle variante lesings in die betrokke variasie-eenheid in die nota opgeneem word, moet slegs die belangrikste lesings opgeneem word, of moet 'n ander uitweg gekies word? Die NAB en NTP verkies die laaste moontlikheid, deur telkens slegs na die vers of verse wat "ontbreek" te verwys. Daar word dus geen lesings in die notas weergegee nie, slegs 'n aanduiding dat daar alternatiewe lesings bestaan. Die uitsondering is Matteus 6:13, waar die doksologie volledig in die nota aangehaal word. Dit is die enigste plek waar 'n variante lesing in die tegniese sin van die woord aangehaal word. Die rede is waarskynlik dat in hierdie enkele geval slegs ' $n$ gedeelte van die vers en nie die hele vers nie, weggelaat is.

In die BB word die saak anders hanteer en word die gedeelte wat nie in die teks voorkom nie, in geheel aangehaal. Daar word dus konsekwent 'n alternatief in die voetnoot vir die lesing in die teks gebied. In Markus 9:43 en 45 word die teks nie uitgeskryf nie, maar kan die leser tog die alternatiewe lesing na aanleiding van die verwysing na vers 48 rekonstrueer. In gevalle waar die BB 'n lang lesing volg en die lesing van 'n nota voorsien (Lk. $22: 19 b-20 ; 43: 44 ; 23: 34$ ), word die woorde in dispuut in blokhakies geplaas sodat die leser presies weet watter woorde in dispuut is. Oor die algemeen gee die BB egter net een alternatiewe lesing in die notas. Slegs in een geval, Johannes 7:53, word meer as een variante lesing in die notas gegee. Nie alleen word die kort lesing hier as alternatief gebied nie, maar ook word die alternatiewe posisies wat die lang lesing in die manuskripte beklee, gegee. In hierdie nota word dus in werklikheid ses variante lesings aan die orde gestel, naamlik die weglating van die betrokke gedeelte, asook die invoeging daarvan in verskillende posisies (na verse 36, 44, 52, Jh. 21:24 en Lk. 21:38).

Die presedent wat in die BB in die geval van Johannes 7:53 geskep word, maak die min inligting wat in ander gevalle gegee word problematies. In Lukas $22: 19 \mathrm{~b}-20 \mathrm{kom}$, byvoorbeeld, ook ses variante lesings voor, terwyl slegs twee in die BB gegee word. In Lukas 22:43-44 kom vyf variante lesings voor, waaronder dieselfde soort transposisie van die lang lesing as in die geval van Johannes 7:53, terwyl slegs twee lesings in die BB se notas gegee word.

Dit is waarskynlik onder andere hierdie relevansie-probleem wat daartoe aanleiding gegee het dat sowel die verwysing na variante lesings as die breër bespreking van die probleem in die BB later in die NTP en NAB weggelaat is en waarom die probleem in hierdie tekste so kort as moontlik aan die orde gestel word.

Die tweede probleem in hierdie verband is die vraag na die hoeveelheid 
inligting wat in die nota gegee moet word, met ander woorde hoe die nota geformuleer moet word. Hierdie probleem word besonder duidelik in die NAB en sy voorgangers weerspieël:

In die notas in die BB word na manuskripte en bepaalde tekskritiese beginsels verwys:

- In sommige gevalle word die keuse van die kort lesing in die vertaling gemotiveer deur 'n verwysing na die "beste manuskripte" teenoor "latere manuskripte" (Mt. 6:13; Mk. 9:43, 45; 16:9; Lk. 23:34; Jh. 7:53).

- Dieselfde beginsel word in ander gevalle met die voorkoms van harmonisasie in die manuskripte gekombineer (Mt. 17:20; 18:11; 23:14; Mk. 7:15; $11: 25 ; 15: 27)$.

- In ander gevalle word slegs gesê dat iets in sommige manuskripte bygevoeg is (Lk. 17:36; 22:19b-20; 23:17; Jh. 5:3; Hd. 8:36; 15:33; 24:6; 28:28).

- Soms word na die "meeste manuskripte" verwys (Lk. 22:43).

In die notas van die NTP word feitlik volledig met bogenoemde weggedoen deurdat feitlik konsekwent na die grondteks verwys word met die woorde: "In die grondteks ontbreek ...." of "In die grondteks kom nie 'n vers . . . voor nie". Daar is twee uitsonderings:

- Markus 16:9: "Volgens die grondteks hou die evangelie hier op. In sommige manuskripte is ' $n$ deel bygevoeg, naamlik vers $9-20$ ".

- Johannes 7:53: "Jh. 7:53-8:11 kom nie in die oudste manuskripte voor nie".

In die NAB word dieselfde praktyk as in die NTP gevolg deurdat feitlik konsekwent na die grondteks verwys word: "In die gebruikte grondteks ontbreek die woorde . . ." of "In die gebruikte grondteks kom nie 'n vers . . . voor nie". Daar is andermaal twee uitsonderings:

- Markus 16:9: "Volgens die gebruikte grondteks hou die evangelie hier op. In sommige manuskripte is 'n deel bygevoeg, naamlik verse 9-20".

- Johannes 7:53: "Volgens die gebruikte grondteks is 7:53-8:11 eers later ingevoeg".

Waar die BB dus verkies om meer inligting te gee, verkies die NTP en NAB om bloot na die grondteks te verwys. Die rede daarvoor is andermaal nie duidelik nie en daar moet op afleidings staatgemaak word om die verskynsel te verklaar. ' $n$ Rede vir hierdie vereenvoudiging van die notas mag dalk wees dat die vertalers gevoel het dat die bespreking in die BB die tekskritiese probleem oorvereenvoudig, terwyl 'n meer bevredigende bespreking van die faktore wat tot die probleem aanleiding gegee het, te veel ruimte in beslag sal neem. 'n Tweede rede mag dalk wees dat die vertalers gevoel het dat 'n verwysing na die manuskripte en na tekskritiese beginsels, die onus van die keuse van die lesing in 'n te groot mate op hulle skouers sou plaas, in plaas 
van op die skouers van die samestellers van die grondteks en dat die keuse van bepaalde 'radikale' lesings op hulle rekening geplaas sou kon word eerder as op die rekening van die samestellers van die grondteks. Hierdie mag redes wees waarom die formulering verander is. Hoe dit ookal sy, dit blyk dat die vereenvoudiging van die notas die saak in die oë van die vertalers minder problematies gemaak het.

Ten opsigte van Markus 16:9 en Johannes 7:53 is daar egter 'n probleem en kan die vertalers nie volhard met 'n blote verwysing na die grondteks nie, juis omdat hulle in hierdie gevalle van die klaarblyklike gebruik om slegs tekste ten opsigte waarvan die OAB 'n langer lesing as die NAB het, van 'n nota te voorsien, afwyk. Om hierdie rede is hulle gedwing om die gebruiklike formulering te verander en met hierdie verandering trap die vertalers presies in die slaggat wat hulle oënskynlik met die verandering in formulering probeer vermy het. Die formulering van die twee notas in die NTP en NAB is ongelukkig en verduister meer as wat dit verhelder. Daar is veral twee probleme:

- In die eerste plek is dit doodeenvoudig verkeerd om te beweer dat die twee gedeeltes (Mk. 16:9-20 en Jh. 7:53-8:11) nie deel van die "gebruikte grondteks" is nie. Ofskoon die samestellers van UBS3 reken dat beide dele nie outentiek is nie, sluit hulle die dele tog by hul teks in: Markus 16:9-20 word by die teks ingesluit, weliswaar tussen dubbelhakies met ' $n$ verklaring in die tekskritiese apparaat dat dit baie seker is dat die verse nie deel van die oorspronklike Markus-evangelie was nie. Tog word dit by die teks ingesluit en word dit nie slegs as 'n variante lesing in die tekskritiese apparaat opgeneem nie. Metzger (1971:128) se verklaring daarvoor lees soos volg: ". . . out of deference to the evident antiquity of the longer ending and its importance in the textual tradition of the Gospel, the Committee decided to include verses 9-20 as part of the text, but to enclose them within double square brackets to indicate that they are the work of an author other than the evangelist" (my kursivering). Hier word duidelik gestel dat die samestellers van die grondteks die betrokke verse as deel van die teks beskou, nieteenstaande die outentisiteitsprobleem. Ten opsigte van Johannes 7:53-8:11 word min of meer dieselfde gesê (Metzger, 1971:221): “Although the Committee was unanimous that the pericope was originally no part of the Fourth Gospel, in deference to the evident antiquity of the passage a majority decided to print it, enclosed within square brackets, at its traditional place following John 7:52" (my kursivering). Hierdie twee aanhalings bewys duidelik dat die betrokke gedeeltes deel van die teks is en nie in die grondteks ontbreek, soos in die betrokke notas beweer word nie. Die onakkuraatheid van die betrokke notas is waarskynlik 'n gevolg van die poging om bondig te wees en nie onnodige inligting te verskaf nie en is as sodanig 'n bewys van die verkeerde beeld wat die bondigheid uiteindelik meebring.

- In die tweede plek wek die formulering van die notas in hierdie twee gevalle die indruk dat die vertalers in hierdie bepaalde gevalle van hulle 
gebruik van die grondteks afwyk en die getuienis van later en swakker manuskripte volg, deur die teks van sulke manuskripte bo die van die grondteks en die oudste en beste manuskripte te verkies. Onmiddellik kan gevra word waarom die lesings van die grondteks in ander gevalle dan gevolg word en nie ook elders buite rekening gelaat word nie. Hierdie formulering wek verkeerdelik die indruk dat die vertalers die gesag van die grondteks, waarop hulle hul in sekere gevalle beroep, ondermyn, terwyl hulle dit in werklikheid nie doen nie. Die hele saak is die gevolg van 'n te bondige formulering van die betrokke notas.

Alles in ag genome, blyk dit dat die keuse ten opsigte van die formulering van hierdie notas tussen drie alternatiewe lê: Die vertaler kan slegs na die grondteks verwys (NTP en NAB). Die vertaler kan 'n kritiese apparaat gee met verwysings na die oorspronklike bronne (soos in die grondteks). Die vertaler kan 'n bespreking van die probleem bied (BB). Al drie alternatiewe het positiewe aspekte en probleme:

- Die eerste alternatief is kort en bondig en bevat slegs die mees basiese inligting. Die vraag is egter hoe effektief en nuttig sulke notas is. Verder bied gevalle soos die notas by Markus 16 en Johannes 7 probleme en blyk dit 'n valse indruk te wek, indien daar in sulke gevalle met 'n blote verwysing na die grondteks volhard word.

- Die voorsiening van 'n volledige kritiese apparaat hou die voordeel in dat iemand met 'n wetenskaplike belangstelling in die teks en tekskritiese $\mathrm{kwessies}$ baat kan vind. Hoeveel waarde dit egter vir die gewone Bybelleser en Bybelgebruiker het, is 'n ope vraag. Hierdie alternatief sal verder ook meebring dat die betrokke vertaling van 'n ekstensiewe inleiding voorsien moet word, waarin die simbooltjies wat in die notas gebruik word, verklaar word en waarin 'n oorsig oor die basiese beginsels van die tekskritiese wetenskap gegee word.

- Die derde alternatief het waarskynlik die grootste nut en bied vir die algemene gebruiker van 'n vertaling die meeste inligting, omdat hy daarin 'n kort beredenering van die probleem kan kry sonder dat hy oor veel wetenskaplike kennis hoef te beskik. Die probleem is egter dat daar in sommige gevalle soveel argumente ter sprake is en soveel fasette aan die tekskritiese probleem verbonde is, dat die bespreking daarvan ' $n$ lang voetnoot tot gevolg sal hê.

Die oplossing van die probleem hang waarskynlik weer saam met die doel van die notas in die teks:

- As die doel van die notas slegs is om aan te toon dat die ontbreking van bepaalde verse nie 'n drukfout is nie, maar aan die grondteks te wyte is, is die verwysing na die grondteks moontlik voldoende. Die voorwaarde is egter dat dit dan slegs in sulke gevalle gebruik moet word en nie in gevalle soos Markus 16:9 en Johannes 7:53 nie. Die vraag is egter of die kool die sous werd is en of die saak nie maar heeltemal daar gelaat kan word of in die voorwoord bespreek kan word nie. 
- Is die doel van die notas om inligting te verskaf ten einde die verandering in vertaling te motiveer, is die blote verwysing na die grondteks onvoldoende en moet sowel ten opsigte van die aantal variante lesings wat by die nota ingesluit word as ten opsigte van die verduideliking en motivering van die keuse van die lesing in die teks, meer gegee word as 'n blote verwysing na die grondteks. In so 'n geval is die derde alternatief hierbo waarskynlik die beste. Hierdie alternatief blyk die nuttigste van almal te wees. Daarom is die notas in die BB waarskynlik meer geslaagd as die in die NTP en NAB.

- Is die doel van die notas om die teksgebruiker op 'n elementêre vlak aan die tekskritiese probleem bloot te stel, bied 'n kombinasie van die tweede en derde alternatiewe, waarin meer inligting aangebied word ten opsigte van die oorspronklike bronne sowel as inligting ten opsigte van die redes waarom ' $n$ bepaalde lesing gekies is, waarskynlik die meeste moontlikhede.

Binne hierdie konteks het die notas van die BB, ofskoon hulle ook nie sonder probleme is nie, waarskynlik die meeste nut.

'n Verwerking en aanpassing van daardie notas kan die nut daarvan aansienlik verhoog.

\section{Die gebruik van blokhakies}

Die derde probleem ten opsigte van die insluiting van tekskritiese notas in 'n vertaling is die vraag of daar in die teks van blokhakies gebruik gemaak moet word. In die BB het die vertalers na analogie van die gebruik deur die samestellers van die grondteks om twyfelagtige lesings in blok- of dubbele blokhakies te plaas, Lukas 22:19b-20; 43-44; 23:34; Markus 16:9-20; en Johannes 7:53-8:11 tussen blokhakies geplaas ter aanduiding dat die outentisiteit daarvan onseker is. Saam met die verwydering van die voetnote by die eerste drie van hierdie tekste het die NTP ook die blokhakies verwyder, sodat dit slegs by Markus 16:9-20 en Johannes 7:53-8:11 behoue gebly het. In die NAB is heeltemal met die gebruik van blokhakies weggedoen.

In die NAB is waarskynlik korrek opgetree. Die gebruik van blokhakies in 'n teks is selfs vir tekskritici en samestellers van die Griekse teks problematies (kyk bv. Elliott, 1973:288-290; 1979; Ross, 1976:115-117; Neill, 1967:14). In 'n vertaling blyk dit geheel en al nutteloos te wees, veral in 'n standaardvertaling. Om blokhakies te gebruik as aanduiding van onsekerheid van die outentisiteit van 'n bepaalde gedeelte sonder om die gebruiker deeglik in te lig ten opsigte van die probleem en die beginsels waarop die saak berus, is kontra-produktief en skep meer verwarring as wat dit verheldering meebring. In 'n vertaling wat as studie-materiaal bedoel is, sou dit waarskynlik nie so problematies gewees het nie. Die voorwaarde is egter dat dit deeglik ter plaatse bespreek word en dat die vertaling van 'n goeie inleiding voorsien word waarin die basiese aspekte van die saak uitgespel word. 


\section{Die voorsiening van 'n Inleiding}

Ten slotte die vraag na die wenslikheid van 'n inleiding waarin die tekskritiese probleem bespreek word.

Dit is 'n vraag hoeveel nut tekskritiese notas binne 'n teks sonder die rugsteuning van 'n inleiding het. Hoe selfverduidelikend die notas ookal mag wees, blyk dit dat 'n inleiding tog onontbeerlik is waar sulke notas in 'n vertaling gebruik word. Die kort, maar verhelderende opmerkings in die Voorwoord van die BB verhoog die nut en waarde van die notas in die BB aansienlik. Daarteenoor verlaag die totale afwesigheid van sulke opmerkings in die NTP en NAB die nut en waarde van die notas in die betrokke vertalings aansienlik. Daarom kan dit as beginsel gestel word dat vertalings wat tekskritiese notas bevat, van 'n inleiding voorsien sal word, waarin die basiese aspekte van die tekskritiek uiteengesit word.

Aan die ander kant is dit egter ook waar dat veral konserwatiewe gebruikers en lesers van die Bybel nie 'n vertaling sal aanvaar waarin te veel 'bykomstighede' voorkom nie. Met hierdie saak moet sekerlik ook rekening gehou word. Dit was een van die belangrikste redes waarom die vertalers van die $\mathrm{OAB}$ die ou en uitgediende Textus Receptus in plaas van 'n beter kritiese uitgawe van die Griekse teks as grondteks gebruik het (kyk Petzer, 1985: 73-87). Binne hierdie konteks is dit ' $n$ vraag of inleidings van hierdie aard nie geheel en al kontra-produktief sal wees en die vertaling vir talle lesers onaanvaarbaar sal maak nie. In so 'n geval is dit waarskynlik beter om geheel en al met sulke notas weg te doen.

\section{Gevolgtrekking}

In die artikel is gepoog om aan die hand van die tekskritiese notas in die NAB 'n oorsig te bied oor verskillende aspekte en probleme waarmee vertalers van die Bybel wat die vertaling van tekskritiese notas wil voorsien, moet rekening hou. Soos die saak tans in die NAB hanteer word, is dit in vele opsigte onbevredigend en word groter verwarring as verheldering deur die notas bewerk, hoofsaaklik omdat te min inligting in die notas voorsien word. Selfs die notas in die BB, hoewel nie sonder probleme nie, het groter waarde as dié in die NAB. Dit sou waarskynlik beter gewees het om die notas in die NAB of heeltemal weg te laat of om notas waarin heelwat meer inligting gegee word en wat deur 'n verduidelikende inleiding gerugsteun word, aan te bied. Soos dit op die oomblik daar staan is dit nog vis nog vlees en kon dit eerder weggelaat gewees het.

Die probleem blyk 'n keuse tussen twee uiterstes te wees, naamlik aan die een kant 'n vertaling waarin geen notas voorkom nie, terwyl dit soms radikaal van ouer vertalings afwyk, of aan die ander kant 'n vertaling met 'n uitgebreide tekskritiese apparaat, gerugsteun deur 'n goeie inleiding. Die eerste sal 
waarskynlik vir die konserwatiewe gebruiker die beste keuse wees, terwyl die leser wat meer in die problematiek van die saak belangstel waarskynlik laasgenoemde sal verkies. In plaas daarvan om een uitgawe van die vertaling voor te berei waarin gepoog word om beide hierdie groepe tevrede te stel, sou dit waarskynlik ' $n$ beter gedagte wees om twee uitgawes van die vertaling voor te berei. Die een kan op die eerste groep gemik wees en kan tradisioneel aangebied word, sonder enige voetnote en verwysings. Die ander kan op die tweede groep gemik wees en kan uitgebreide verwysings na tekskritiese (en ook ander) sake bevat. 'n Mens wonder of die tyd nie ryp is vir die verskyning van 'n Afrikaanse geannoteerde Bybel nie, waarin formele aspekte wat normaalweg nie in die Bybel met Verklarende Aantekeninge aandag ontvang nie, op 'n kort en duidelike manier belig kan word.

\section{Bibliografie}

Die volgende afkortings word ter verwysing na Griekse tekste en vertalings gebruik:

$\mathrm{BB}$

NAB

NA26

$\mathrm{OAB}$

\section{Afrika.}

Oxford GNT - THE AMERICAN AND BRITISH COMMITTEES OF THE INTERNATIONAL GREEK NEW TESTAMENT PROJECT (samest.). 1984. The New Testament in Greek. The Gospel according to St. Luke, pt.1: chapters 1-12. Oxford: Clarendon.

UBS3

- Aland, K., Black, M., Martini, C.M., Metzger, B.M. \& Wikgren, A.P. (samest.). 1975. The Greek New Testament. 3e uitg. London: United Bible Societies.

\section{Geraadpleegde werke:}

Elliott, J.K. 1973. The United Bible Societies' Greek New Testament: an evaluation. Novum Testamentum 15:278-300.

Elliott, J.K. 1975. A second look at the United Bible Societies' Greek New Testament. The Bible Translator 26:325-332.

Elliott, J.K. 1979. The use of brackets in the text of the United Bible Societies' Greek New Testament. Biblica 60:575-577.

Elliott, J.K. 1986. The purpose and construction of a critical apparatus to a Greek New Testament. (In W. Schrage (red.). Studien zum Text und Ethik des Neuen Testaments. Festschrift zum 80. Geburtstag von Heinrich Greeven. Berlin: De Gruyter. p.125-143.)

Finegan, J. 1974. Encountering New Testament manuscripts. A working introduction to textual criticism. Grand Rapids: Eerdmans.

Junack, K. 1978. The reliability of the New Testament text from the perspective of textual criticism. The Bible Translator 29:128-140.

Kilpatrick, G.D. 1978. A Textus Receptus redevivus? Center for Hermeneutical Studies 32:1-17.

Markham, R.P. 1966. The Bible Societies' Greek Testament: the end of a decade or the beginning of an era? The Bible Translator 17:106-113.

Metzger, B.M. 1971. A textual commentary on the Greek New Testament. United Bible Societies. 
Neill, S.C. 1967. The Bible Societies' Greek New Testament: a symposium. B: Review. The Bible Translator 180:12-15.

Petzer, J.H. 1985. Die grondteks vir die vertaling van die Nuwe Testament in die Afrikaanse Bybel. Literator 6(3):73-87.

Ross, J.M. 1976. The United Bible Societies' Greek New Testament. Journal of Biblical Literature 5:112-121. 